\title{
Czy u chorych na HER2-dodatniego raka piersi z przerzutem do mózgu rozpoznanym w trakcie leczenia trastuzumabem należy zmienić lek? Głos na TAK
}

\author{
Renata Duchnowska

\begin{abstract}
We should change the current treatment in HER2-positive breast cancer patients with brain metastases developed during trastuzumab administration
\end{abstract}

\begin{abstract}
Wstęp
Rak piersi z nadmierną ekspresją lub amplifikacją genu HER2 („HER2-dodatni”) cechuje się szczególną agresywnością, przejawiającą się między innymi zwiększonym ryzykiem przerzutów do mózgu. Skumulowane 10-letnie ryzyko wystąpienia przerzutów do mózgu u chorych na HER2-dodatniego raka piersi jest blisko 3-krotnie wyższe niż u chorych na raka HER2-ujemnego (odpowiednio 2,6\% i 0,9\%) [1]. U chorych na HER2-dodatniego raka piersi skojarzenie chemioterapii lub hormonoterapii z monoklonalnym przeciwciałem anty-HER2, trastuzumabem, wydłuża czas wolny do nawrotu (diesease-free survival — DFS) oraz czas ogólnego przeżycia (overall survival — OS). Paradoksalnie, dłuższe przeżycie oznacza jednak także większe prawdopodobieństwo ujawnienia się późnych przerzutów w mózgu. Zbiorcza analiza wyników badań, w których oceniano skuteczność trastuzumabu w uzupełniającym leczeniu, wykazała wzrost względnego ryzyka (relative risk - RR) przerzutów do mózgu o 57\% (1,57; 95\% zakres ufności [confidence interval - Cl] 1,03-2,37; $p=0,033$ ) [2]. Obserwację tę potwierdzono w danych z rejestru prowincji Parma: ryzyko izolowanych przerzutów do mózgu u chorych na HER2-dodatniego raka, którzy otrzymali leczenie trastuzumabem, wynosiło 4\%, u nieleczonych 1,2\%, a u chorych na raka HER2-ujemnego $0,6 \%(p=0,035)[3]$. W innej retrospektywnej obserwacji odsetek izolowanych przerzutów do mózgu u chorych otrzymujących trastuzumab w uzupełniającym leczeniu był także wyższy [4]. Z drugiej strony w rejestrze prowincji Parma czas
\end{abstract}

do pojawienia się przerzutów do mózgu u chorych na HER2-dodatniego raka leczonych i nieleczonych trastuzumabem wynosił odpowiednio 20,3 i 10,3 miesiąca ( $p=0,018)$, co wynika jednak $z$ aktywności tego leku poza ośrodkowym układem nerwowym [3]. Z kolei u chorych na HER2-dodatniego, zaawansowanego raka piersi skumulowane ryzyko wystąpienia objawowych przerzutów do mózgu szacuje się na 10-40\% [3, 5-14], a średnie roczne ryzyko na około 10\% [14]. Podobnie jak w leczeniu uzupełniającym, leczenie trastuzumabem w rozsianym raku piersi znacząco opóźnia ujawnienie się objawowych przerzutów do mózgu (w badaniu Dawood i wsp. [15] mediana odpowiednio 13.1 w porównaniu z 2,1 miesiąca u chorych nieleczonych, a w badaniu Park i wsp. [16] - 19 i 7,8 miesiąca). W 85-90\% przypadków przerzuty w OUN są wieloogniskowe, poza możliwościami leczenia chirurgicznego lub stereotaktycznej radiochirurgii (stereotatic radiosurgery — SRS) [11, 16, 17-20]. U chorych na zaawansowanego HER2-dodatniego raka piersi progresji w mózgu często towarzyszy kontrola pozaczaszkowych ognisk choroby, a u połowy chorych z przerzutami do mózgu są one przyczyną zgonu.

\section{Miejscowe leczenie przerzutów do mózgu u chorych na raka piersi}

Niezależnie od fenotypu raka piersi algorytm miejscowego leczenia przerzutów do mózgu jest uwarunkowany głównie stanem ogólnym chorej — KPS (Karnofsky Performance Status), lokalizacją przerzutów w mózgu i ich liczbą

\section{Klinika Onkologii}

Wojskowego Instytutu Medycznego w Warszawie

Wystąpienie podczas II Konferencji Naukowej czasopisma Nowotwory „Debaty onkologiczne” 11-12 kwietnia 2014 roku 
oraz obecnością pozaczaszkowych ognisk rozsiewu. Jeśli liczba przerzutów w mózgu nie przekracza 3, KPS wynosi co najmniej 70, a inne ogniska choroby są pod kontrolą, zaleca się leczenie chirurgiczne lub SRS, ewentualnie uzupełnione napromienianiem całego mózgowia (whole brain radiation therapy - WBRT). U chorych podlegających regularnym kontrolnym badaniom obrazowym (magnetyczny rezonans [MR] co 2-3 miesiące) można odstąpić od WBRT i zastosować je w przypadku progresji [21]. Pozwala to uniknąć neuropoznawczych zaburzeń i nie ma niekorzystnego wpływu na czas całkowitego przeżycia. W przypadku większej liczby przerzutów w mózgu leczeniem z wyboru pozostaje WBRT w dawce 20-30 Gy, podanej w 5-10 frakcjach. U chorych z KPS poniżej 70 lub ze współistnieniejącymi pozaczaszkowymi ogniskami nowotworu zaleca się WBRT, uzupełnione w przypadku pojedynczej zmiany przez SRS [22, 23].

\section{Biologia przerzutów do mózgu u chorych na HER2-dodatniego raka piersi}

Patomechanizm powstawania przerzutów do mózgu nie jest do końca poznany. W mysim modelu wykazano, że nadekspresja HER2 związana jest z wyższym ryzykiem powstania przerzutów do mózgu [24]. U człowieka, w procesie tzw. „,kolonizacji mózgu“, istnieje szereg powiązanych ze sobą procesów, przy istotnym wpływie aktywacji somatycznych mutacji w komórkach guza pierwotnego piersi np. EGFR, HRAS, KRAS, NRAS, PIK3CA, PTEN oraz odpowiedzi mikrośrodowiska mózgu [25, 26]. W kilku badaniach u chorych na HER2-dodatniego raka piersi stwierdzono równoczesną nadmierną ekspresję HER2 oraz HER1 (epidermal growth factor receptor - EGFR) w poddanych resekcji przerzutach do mózgu [27-30]. Wskazywano także, że kluczową rolę w kolonizacji mózgu może odgrywać ekspresja HER3 i jej aktywacja przez neuroregulinę [25]. Co ciekawe, w wielu procesach chorobowych zachodzących w mózgu aktywacja HER1 związana jest z powstaniem reaktywnych astrocytów [31]. W przerzutach do mózgu przypisuje się im działanie chemioprotekcyjne oraz wzrost aktywności heparynaz i metaloproteinaz macierzy zewnątrzkomókowej [26]. W świetle tych doniesień racjonalne wydaje się stosowanie terapii skierowanych nie tylko na HER2, ale również na inne receptory rodziny HER.

\section{Systemowe leczenie chorych na HER2-dodatniego raka piersi z przerzutami do mózgu}

Brakuje opartych na wynikach prospektywnych badań klinicznych zaleceń dotyczących rodzaju chemioterapii lub leczenia celowanego u chorych z przerzutami do mózgu [32-34]. Opublikowane w roku 2014 zalecenia American Society of Clinical Oncology (ASCO) w przypadku wystąpienia przerzutów w mózgu dopuszczają kontynuację leczenia trastuzumabem [32]. Zalecenia ASCO, National Comprehensive Cancer Network i European Society for Medical
Oncology nie uwzględniają jednak w ocenie odpowiedzi na leczenie jego rodzaju oraz lokalizacji w tzw. „niedostępnych" miejscach (sanctuary site), do których należy mózg. Za progresję choroby (progressive disease - PD) uważa się postęp nowotworu pomimo zastosowanego leczenia. Co więcej, według kryteriów RECIST (Response Evaluation Criteria in Solid Tumors) w wersji 1.1 stwierdzenie przerzutów w mózgu w kontrolnym badaniu obrazowym (komputerowa tomografia lub MR) w trakcie leczenia traktowane jest jako progresja, niezależnie od tego, czy badania te wykonano przed rozpoczęciem systemowego leczenia [35].

W kilku retrospektywnych badaniach wykazano wydłużenie OS u chorych otrzymujących trastuzumab po wystąpieniu przerzutów do mózgu, jednak nie było to związane z kontrolą mózgowych ognisk choroby [16, 1820]. Niezależnie od tego brak randomizacji nie zapewnia równomiernego doboru chorych w porównywanych grupach (jest np. prawdopodobne, że chorzy kwalifikowani do kontynuacji leczenia trastuzumabem byli w lepszym stanie ogólnym czy z mniejszą liczbą zmian przerzutowych). W jedynym badaniu z randomizacją, oceniajacym skuteczność kontynuacji leczenia trastuzumabem po progresji, udział chorych z przerzutami do mózgu był znikomy (łącznie 3 chore) [36]. Biorąc pod uwagę znaczną częstość mózgowej lokalizacji przerzutów w zaawansowanym HER2-dodatnim raku piersi, sytuacja ta wskazuje, że takie chore niechętnie włączano do badania. Z kolei w małym retrospektywnym badaniu wykazano, że u chorych z przerzutami do mózgu zastosowanie niskocząsteczkowego inhibitora kinaz tyrozynowych HER1 i HER2, lapatynibu w połączeniu z kapecytabiną (schemat LC), jest skuteczniejsze niż schematy zawierające trastuzumab (mediana całkowitego przeżycia wynosi odpowiednio 19 i 12 miesięcy, $p=0,04$ ), jednak bez wpływu na odsetek zgonów z powodu progresji mózgowej (32\% vs $43 \%, p=0,3)$ [17].

Za zmianą leczenia u chorych leczonych trastuzumabem po progresji w mózgu przemawiają pośrednie dowody wskazujące, że we wtórnej profilaktyce przerzutów do mózgu skuteczniejsze może być leczenie hamujące wewnątrzkomórkowe szlaki sygnałowe HER2 i HER1. W rejestracyjnym badaniu porównującym skuteczność schematu LC i monoterapii kapecytabiną u chorych z progresją w trakcie terapii trastuzumabem udział objawowych przerzutów do mózgu w obu grupach wynosił odpowiednio $2 \%$ i $6 \%(p=0,045)$ [37]. Różnicy tej towarzyszyło wydłużenie czasu do progresji (PFS) - mediana odpowiednio 8,4 i 4,4 miesiąca, względne ryzyko (hazard risk - HR) 0,49; $\mathrm{p}<0,001$. Efektu takiego nie obserwowano w badaniu GBG-26/BIG03-05, porównującym u chorych z progresją w trakcie leczenia trastuzumabem - schemat zawierający trastuzumab z kapecytabiną (TC) z monoterapią kapecytabiną — udział przerzutów do mózgu w obu grupach wynosił odpowiednio 14\% i 8\% (różnica nieznamienna) [36]. Równocześnie jednak korzyść z dodania 
leczenia anty-HER2 do chemioterapii w zakresie czasu do progresji była porównywalna do osiągniętej we wcześniej cytowanym badaniu rejestracyjnym lapatynibu [37] (mediana odpowiednio 8,2 i 5,6 miesiąca; HR 0,69; $p=0,034$ ). W innym prospektywnym, nierandomizowanym badaniu porównującym schematy LC i TC wykazano numeryczną, choć statystycznie nieznamienną różnicę w odsetku przerzutów do mózgu na korzyść schematu LC (odpowiednio $3 \%$ i $12 \% ; p=0,16)[38]$.

Aktywność schematu LC w leczeniu przerzutów do mózgu u chorych na HER2-dodatniego raka piersi potwierdzają również wyniki badania LANDSCAPE, w którym uzyskano aż $66 \%$ odpowiedzi na leczenie oraz względnie długi czas do progresji w mózgu (mediana 5,5 miesiąca) [39]. W badaniu EGF105084, w którym stosowano monoterapię lapatynibem u chorych z progresją w mózgu po wcześniejszej WBRT, u $42 \%$ chorych uzyskano stabilizację choroby i u $6 \%$ częściową odpowiedź [40]. Co ciekawe, u chorych z progresją w trakcie leczenia lapatynibem dołączenie kapecytabiny pozwoliło uzyskać około 20\% częściowych odpowiedzi. Z kolei w badaniu CEREBEL (EGF111438), w którym chorzy po chemioterapii zawierającej antracykliny i taksoidy w 1 . linii leczenia anty-HER2 otrzymywali schematy TC lub LC, odsetek bezobjawowych przerzutów do mózgu jako pierwszej lokalizacji niepowodzenia wynosił odpowiednio 3\% i 4\% [41]. Badanie to zostało przedwcześnie zakończone w związku z korzyścią w zakresie PFS i OS w ramieniu TC w porównaniu z LC (mediana PFS odpowiednio 8 i 6,6 miesiąca [HR 1,3; 95\% Cl: 1,0-1,7]; mediana OS: 27,3 i 22,4 miesiąca [HR 1,58; $95 \%$ Cl: 1,07-2,32]. Niezależnie od częstości występowania przerzutów do mózgu u chorych na HER2-dodatniego raka piersi oraz postępów w leczeniu aktywne poszukiwanie bezobjawowych zmian w mózgu nie wpływa na poprawę parametrów przeżycia i nie jest zalecane [42]. Postępowanie takie w praktyce klinicznej może wręcz utrudniać decyzje terapeutyczne, zwłaszcza jeżeli przed rozpoczęciem leczenia nie wykonano obrazowych badań mózgu.

\section{Podsumowanie}

Brakuje danych z prospektywnych badań III fazy, pozwalających na wybór optymalnego postępowania u chorych na HER2-dodatniego raka piersi z pojedyczym lub izolowanym przerzutem do mózgu wykrytym w trakcie leczenia trastuzumabem. Pośrednie dowody przemawiają jednak za zmianą leczenia anty-HER2. Mózg jest miejscem szczególnej lokalizacji przerzutów, bowiem bardzo ograniczone przenikanie większości leków przeciwnowotworowych przez barierę krew-mózg powoduje, że ich stężenie w płynie mózgowo-rdzeniowym nie osiaga terapeutycznych wartości. Sytuacja ta dotyczy w szczególności trastuzumabu - monoklonalnego przeciwaciała o masie cząsteczkowej około 145 kDa, którego stężenie w płynie mózgowo-rdze- niowym stanowi jedynie około 1/420 stężenia w surowicy [43]. Przenikanie niskocząsteczkowych inhibitorów kinazy tyrozynowej HER2, takich jak lapatynib, jest znacznie większe, a ich połączenie z niektórymi lekami cytotoksycznymi pozwala uzyskać istotną klinicznie odpowiedź w obrębie mózgu. Niezależnie od tego koncepcja kontynuowania leczenia trastuzumabem u chorych z progresją w obrębie mózgu przy kontroli pozaczaszkowych ognisk choroby, która zawarta jest w niektórych międzynarodowych zaleceniach, nie da się w Polsce zrealizować w ramach obecnego programu leczniczego.

Wiele nowych leków anty-HER2, w tym drobnocząsteczkowe inhibitory kinazy tyrozynowej (neratynib, afatynib), monoklonalne przeciwciała (trastuzumab DM1, pertuzumab) oraz inhibitory mTOR i deacetylazy histonowej znajdują się obecnie w fazie zaawansowanych badań klinicznych, a dane na temat ich aktywności w leczeniu przerzutów do mózgu są skąpe.

\section{Dr hab. n. med. Renata Duchnowska}

Klinka Onkologii

Wojskowy Instytut Medyczny w Warszawie

ul. Szaserów 128, 04-141 Warszawa

e-mail:rdtt@wp.pl

\section{Piśmiennictwo}

1. Pestalozzi BC, Zahrieh D, Price KN i wsp. Identifying breast cancer patients at risk for Central Nervous System (CNS) metastases in trials of the International Breast Cancer Study Group (IBCSG). Ann Oncol 2006; 17: 935-944.

2. Bria E, Cuppone F, Fornier M i wsp. Cardiotoxicity and incidence of brain metastases after adjuvant trastuzumab for early breast cancer: the dark side of the moon? A meta-analysis of the randomized trials. Breast Cancer Res Treat 2008; 109: 231-239.

3. Musolino A, Ciccolallo L, Panebianco M i wsp. Multifactorial central nervous system recurrence susceptibility in patients with HER2-positive breast cancer: epidemiological and clinical data from a population-based cancer registry study. Cancer 2011; 117: 1837-1846.

4. Yap YS, Cornelio GH, Devi BC i wsp. Brain metastases in Asian HER2-positive breast cancer patients: anti-HER2 treatments and their impact on survival. Br J Cancer 2012; 107: 1075-1082.

5. Bendell JC, Domchek SM, Burstein HJ i wsp. Central nervous system metastases in women who receive trastuzumab — based therapy for metastatic breast carcinoma. Cancer 2003; 97: 2972-2977.

6. Clayton AJ, Danson S, Jolly S i wsp. Incidence of cerebral metastases in patients treated with trastuzumab with trastuzumab for metastatic breast cancer. Br J Cancer 2004; 91: 639-643.

7. Shmueli E, Wigler N, Inbar M. Central nervous system progression among patients with metastatic breast cancer responding to trastuzumab treatment. Eur J Cancer 2004; 40: 379-382.

8. Lower EE, Drosick RD, Blau R i wsp. Increased rate of brain metastases with trastuzumab therapy not associated with impaired survival. Clin Breast Cancer 2003; 4: 114-119.

9. Lai R, Dang CT, Malkin MG i wsp. The risk of central nervous system metastases after trastuzumab therapy in patients with breast carcinoma. Cancer 2004; 101: 810-816.

10. Stemmler, HJ, Kahlert S, Siekiera W i wsp. Characteristics of patients with brain metastases receiving trastuzumab for HER2 overexpressing metastatic breast cancer. Breast 2006; 15: 219-225.

11. Burstein $\mathrm{HJ}$, Lieberman $\mathrm{G}$, Slamon DJ i wsp. Isolated central nervous system metastases in patients with HER2 overexpressing advanced breast cancer treated with first-line trastuzumab based therapy. Ann Oncol 2005; 16: 1772-1777.

12. Arif SS, Jordan CE, Thomas M i wsp. A study to determine the incidence and treatment outcome of brain metastases in patients treated with 
trastuzumab for metastatic breast cancer (MBC). Clin Oncol 2004; 16: S44.

13. Yau T, Swanton C, Chua S i wsp. Incidence, pattern and timing of brain metastases among patients with advanced breast cancer treated with trastuzumab. Acta Oncol 2006; 45: 196-201.

14. Duchnowska R, Dziadziuszko R, Czartoryska-Arłukowicz B i wsp. Risk factors for brain relapse in HER2-positive metastatic breast cancer patients. Breast Cancer Res Treat 2009; 117: 297-303.

15. Dawood S, Broglio K, Esteva FJ i wsp. Defining prognosis for women with breast cancer and CNS metastases by HER2 status. Ann Oncol 2008; 19: 1242-1248.

16. Park IH, Ro J, Lee KS i wsp. Trastuzumab treatment beyond brain progression in HER2-positive metastatic breast cancer. Ann Oncol 2009; 20: 56-62.

17. Kaplan MA, Isikdogan A, Koca D i wsp. Clinical outcomes in patients who received lapatinib plus capecitabine combination therapy for HER2-positive breast cancer with brain metastasis and a comparison of survival with those who received trastuzumab-based therapy: a study by the Anatolian Society of Medical Oncology. Breast Cancer 2013 Jan 19. [Epub ahead of print].

18. Metro G, Sperduti I, Russillo M i wsp. Clinical utility of continuing trastuzumab beyond brain progression in HER-2 positive metastatic breast cancer. Oncologist 2007; 12: 1467-1469.

19. Church DN, Modgil R, Guglani S i wsp. Extended survival in women with brain metastases from HER2 overexpressing breast cancer. Am $J$ Clin Oncol 2008; 31: 250-254.

20. Gori S, Rimondini S, De Angelis V i wsp. Central nervous system metastases in HER-2 positive metastatic breast cancer patients treated with trastuzumab: incidence, survival, and risk factors. Oncologist 2007; 12: 766-773.

21. www.astro.org

22. Mintz A, Perry J, Spithoff K i wsp. Management of single brain metastasis: a practice guideline. Curr Oncol 2007; 14: 131-143.

23. Eichler AF, Loeffler JS. Multidisciplinary management of brain metastases. Oncologist 2007; 12: 884-898.

24. Palmieri D, Bronder JL, Herring JM i wsp. Her-2 overexpression increases the metastatic outgrowth of breast cancer cells in the brain. Cancer Res 2007; 67: 4190-4198.

25. Da Silva L, Simpson PT, Smart CE i wsp. HER3 and downstream pathways are involved in colonization of brain metastases from breast cancer. Breast Cancer Res 2010; 12: R46.

26. Fitzgerald DP, Palmieri D, Hua E i wsp. Reactive glia are recruited by highly proliferative brain metastases of breast cancer and promote tumor cell colonization. Clin Exp Metastasis 2008; 25: 799-810.

27. Hines SL, Vallow LA, Tan WW i wsp. Clinical outcomes after a diagnosis of brain metastases in patients with estrogen- and/or human epidermal growth factor receptor 2-positive versus triple-negative breast cancer. Ann Oncol 2008; 19: 1561-1565.
28. Nam, BH, Kim SY, Han HS i wsp. Breast cancer subtypes and survival in patients with brain metastases. Breast Cancer Res 2008; 10: R20.

29. Eichler AF, Kuter I, Ryan P i wsp. Survival in patients with brain metastases from breast cancer: the importance of HER-2 status. Cancer 2008; 112: 2359-2367.

30. Hohensee I, Lamszus K, Riethdorf Si wsp. Frequent genetic alterations in EGFR- and HER2-driven pathways in breast cancer brain metastases. Am J Pathol 2013; 183: 83-95.

31. Liu B, Neufeld AH. Activation of epidermal growth factor receptors in astrocytes: from development to neural injury. J Neurosci Res 2007; 85: 3523-3529.

32. Ramakrishna N, Temin S, Chandarlapaty Si wsp. Recommendations on disease management for patients with advanced human epidermal growth factor receptor 2-positive breast cancer and brain metastases: American Society of Clinical Oncology clinical practice quideline. J Clin Oncol 2014; 32: 2100-2108.

33. www.fda.gov.

34. Lin NU. Targeted therapies in brain metastases. Curr Treat Options Neurol 2014; 16: 276.

35. Eisenhauer EA, Therasse $P$, Bogaerts J i wsp. New response evaluation criteria in solid tumours: revised RECIST guideline (version 1.1). Eur J Cancer 2009; 45: 228-247.

36. von Minckwitz G, Schwedler K, Schmidt M i wsp. Trastuzumab beyond progression: overall survival analysis of the GBG 26/BIG 3-05 phase III study in HER2-positive breast cancer. Eur J Cancer 2011; 47: 2273-2281.

37. Geyer CE, Forster J, Lindquist D i wsp. Lapatinib plus capecitabine for HER2-positive advanced breast cancer. N Engl J Med 2006; 355: 2733-2743.

38. Bian L, Wang T, Zhang S i wsp. Trastuzumab plus capecitabine vs. lapatinib plus capecitabine in patients with trastuzumab resistance and taxane-pretreated metastatic breast cancer. Tumour Biol 2013; 34: 3153-3158.

39. Bachelot T, Romieu G, Campone M i wsp. Lapatinib plus capecitabine in patients with previously untreated brain metastases from HER2-positive metastatic breast cancer (LANDSCAPE): a single-group phase 2 study. Lancet Oncol 2013; 14: 64-71.

40. Lin NU, Diéras V, Paul D i wsp. Multicenter phase II study of lapatinib in patients with brain metastases from HER2-positive breast cancer. Clin Cancer Res 2009; 15: 1452-1459.

41. Pivot X, Hackmann J, Manikhas A i wsp. Incidence Rate of Asymptomatic Brain Metastases in Patients with HER2+ Metastatic Breast Cancer Screened for EGF111438/CEREBEL Study. Cancer Res 2011; 71 (24) Suppl. 3.

42. Niwińska A, Tacikowska M, Murawska M. The effect of early detection of occult brain metastases in HER2-positive breast cancer patients on survival and cause of death. Int J Radiat Oncol Biol Phys 2010; 77: 1134-1139.

43. Stemmler $\mathrm{H}-\mathrm{J}$, Schmitt M, Willems A i wsp. Ratio of trastuzumab levels in serum and cerebrospinal fluid is altered in HER2-positive breast cancer patients with brain metastases and impairment of the blood-brain barrier. Anticancer Drugs 2007; 18: 23-28. 